\title{
MULTI-COUNTRY STUDY OF BANK CREDIT RISK DETERMINANTS
}

\author{
Nor Hayati Ahmad and Mohamed Ariff \\ University Utara Malaysia and \\ Bond University, Australia
}

\begin{abstract}
This paper presents fresh findings about key determinants of credit risk of commercial banks in emerging economy banking systems compared with developed economies. Australia, France, Japan and the US represent developed economies; emerging economies are India, Korea, Malaysia, Mexico and Thailand. Credit risk theories and empirical literature suggest eight credit risk determinants. We find anywhere from two to four factors are alone significantly correlated with credit risk of any one banking system. Regulatory capital is significant for banking systems that offer multi products; management quality is critical in the cases of loan-dominant banks in emerging economies. Contrary to theory or studies, we find leverage is not correlated with credit risk in our test period. Data transformations and statistical corrections ensured these results are reliable: Model robustness was tested using AIC. The model developed here could be applied to test more emerging economy banking systems to generalize our findings to other economies.
\end{abstract}

\section{JEL Classification. F28}

Key words: Bank risk management; credit risk; regulatory capital; emerging economies.

\section{Introduction}

A survey of the literature shows that, among the studies of bank credit risk determinants, there are currently few publications on (a) multi-country comparisons that (b) incorporate a multi-factor modeling to study credit risk determinants. Studies on bank credit risk are mostly in a single country setting; secondly, much attention is directed to developed country banks. This paper presents a comparative study of all factors contributing to credit risk of commercial

\footnotetext{
* Editorial Note: This paper was one of three best papers selected by the previuos Editor of IJBF at the FMA-Asian Finance Association's $200517^{\text {th }}$ conference. The co-author of this paper commenced duties as co-editor of IJBF in 2007, and did not have any part in the selection/review of this paper.
} 
banks in a multi-country setting: Australia, France, Japan and the U.S. represent developed economies while emerging economy banking systems are represented by India, Korea, Malaysia, Mexico and Thailand. The findings in several studies lend support to the theory that changes in international and national macroeconomic variables, which are systematic in nature, and a set of unsystematic bank-specific factors influence the formation of bank credit risk (see DemirgucKunt, 1989; Corsetti, Pesenti and Roubini, 1998; Neal, 1996; Ariff and Marisetty, 2001, Bikker and Metzemakers, 2004; Cebenoyan and Strahan, 2004, and Kraft and Jankov, 2005). We take these findings as our starting point for our research process, and report significant new findings in this paper. This study is limited to the bank-specific variables except for few market-wide factors.

Among the factors used to identify risk, non-performing loan (NPL) or impaired loan is a factor that has received central focus in the analysis of how credit risk built-up after the 1997 Asian Financial Crisis (Takayasu et al., 2000) in the affected banking systems. This variable is widely used as credit risk. Table

Table 1: Non-performing loans of financial systems . Non-performing loan is defined as the percentage of loan values that are not serviced for three or more months. Banking crises were identified in each country.

Futing Banking Crises Ftring Norisat Times

\begin{tabular}{|c|c|c|c|c|c|}
\hline \multicolumn{4}{|c|}{ Dturing Banking Crises } & \multicolumn{2}{|c|}{ Thtritg Norisat Jinses } \\
\hline \multicolumn{2}{|c|}{ bevelonthe somomics } & \multicolumn{2}{|c|}{ beveinoed samonies } & \multicolumn{2}{|c|}{ beredoned economics } \\
\hline & (\%) & & $(\%)$ & & $(\%)$ \\
\hline -Indonesia & 49 & $\cdot \mathrm{L}$ IS & $4 *$ & Canada & 1.92 \\
\hline - Thailand & 48 & *Nordic countries & 10 & Deninark & 092 \\
\hline - Malaysin & 19 & - Japan estinate & $\mathrm{g}$ & If kingdom & 4.62 \\
\hline & & - Korea & 8 & Irance & 1,78 \\
\hline
\end{tabular}

Duritig Benkthg Criecs During Norme Times

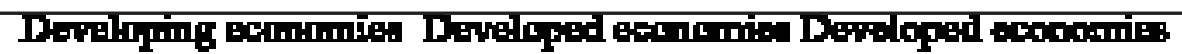

$(\times)$

(\%)

-Indonenir 49 -US

Thring 4

Malygis
4

-Nardic esmmtries

19 Jopan atiminge

-Kore:
4 * Caneda

10

Demmatk

U. Kingiom

g Frintas
(4)

192

0.92

4,62

1.78

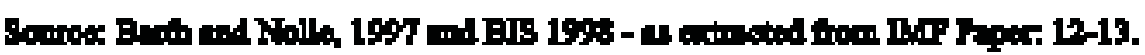

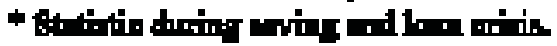


1 illustrates this: NPL in developing economies is almost 10 times higher compared to that in the U.S. banking system or 5 times higher than that of Japanese and Korean banks.

Among external factors, economic downturn is a significant determinant of credit risk (Fisher, Gueyie and Ortiz, 2000; Ahmad, 2003; Bikker and Metzemakers, 2004 and Kraft and Jankov, 2005). During such downturns, the quality of bank assets is likely to deteriorate, which would increase the risk of the bank, and it could require an increase in capital requirements, which if the banks are weaker, are very costly or may simply be unobtainable (Bikker and Meltzemakers, 2004) during a period of crisis. Most banks in economies such as Thailand, Indonesia, Malaysia, Japan and Mexico experienced high nonperforming loans and significant credit risk rises during financial and banking crises, which resulted in the closing down of several banks in Indonesia and Thailand.

In the case of Malaysia, no bank was closed down but the weaker banks were required to merge with others to strengthen their capital base, which was eroded by huge accumulated losses due to impairment of loans. Subsequently, stronger commercial banks (which were later known as the ten anchor banks) were required by the central bank to acquire these banks. The exercise involving injection of new experienced top management resulted in a massive restructuring of the entire banking system in 1999-2000 (Ahmad, 2003).

Although a larger number of banks in developing (in particular, Asean) economies are worst hit by credit risk in the test period compared to their developed counterparts, not much research attention has been given to the factors responsible for high credit risk in these countries in that period. Most existing studies of credit risk determinants were those relating to developed markets (See Hassan et al., 1994; Gallo et al., 1996; Galloway et al. 1997; Fischer et al., 2000; Bikker and Meltzemakers, 2004, Jimenez and Saurina, 2004; Kraft and Jangkov, 2005). Other studies on changes in risk premiums were conducted in the U.S. (See Elyasiani and Mansur, 1998) and Ariff and Marisetty, 2001) using a multi-country risk premium modeling of firms in 22 OECD countries.

This study has opted for a wider approach to this research issue by investigating all factors contributing to credit risk across two sets of countries, developed and developing. We also develop a more comprehensive credit risk model by incorporating a different and comprehensive set of variables. The data set contains 23,499 bank years of observations covering nine countries over a crisis-prone period, 1996 to 2002. This multi-factor and multi-country approach allows us to compare and then identify whether there exists major differences in credit risk determinants across countries in different developmental stage.

The rest of the paper is organised as follows. Section 2 contains a review of theory and related literature. Section 3 describes the methodology and that is followed by an analysis of results in Section 4. Section 5 concludes the paper. 


\section{Literature review on credit risk and determinants}

\subsection{Theory}

This study is conducted against the backdrop of three main theories on risk: Sharpe's (1963) Capital Asset Pricing Theory (CAPM), Markowitz's (1959) Portfolio Theory and Hamada's (1972) theory on risk and leverage. The CAPM suggests that price or expected return of an asset is related to its risk-free rate, the systematic risk and the expected risky market's risk-premium.

Hence,

$$
E\left(R_{j}\right)=R_{f}+\beta_{j}\left[E\left(R_{m}-R_{f}\right)\right]
$$

Where,

$E\left(R_{j}\right):$ the expected return on the asset $j=1, \ldots, N$,

$\mathrm{R}_{\mathrm{f}} \quad:$ the risk-free rate of return measured as treasury bill/bond yield,

$\mathrm{R}_{\mathrm{m}} \quad$ : the expected return for the risky market portfolio,

$\beta_{\mathrm{j}} \quad$ : the individual asset's systematic risk relative to the risky mar ket's portfolio, and

$E\left(R_{m}-R_{f}\right)$ : the expected risk-premium of risky market portfolio.

Applied to a portfolio of bank loans, bank managers may be said to maintain a combination of loans with varying risk levels. The portfolio of bank loans would have to be such that the overall risk of the loans is diversified given the covariance of returns from each pair of loans is likely to be such that the correlation coefficient is closer to 0 rather than exactly equal to +1.00 as suggested by the Markowitz for diversifying individual asset's (loan) risk. Equation 1 denotes that, for risky loans, bank managers would charge a premium equal to the difference between the overall risk-premium applicable in the 'market' for all the loans in the market $\left(\mathrm{R}_{\mathrm{t}}-\mathrm{R}_{\mathrm{mt}}\right)$ in order for the banks to compensate themselves for the additional risk of a particular loan. In essence, the CAPM infers that the required rate of return demanded by banks is equal to a risk-free rate (equivalent to the yield of a Treasury instrument with the same term as that of the loan) plus a premium as determined in the market for the total loan holding.

Accordingly, a bank will price its loans according to the level of risk perceived whereby a perceived higher (lower) risk loan will attract a higher (lower) price for lending. Since individual loan risk can be eliminated through loan diversification as stated by Markowitz, the risk that a bank is concerned with in its loan-pricing decision is the market risk and the price of risk is:

$$
\text { Price of risk }=\text { unit of risk } x \text { risk-premium }=\beta_{j}\left[E\left(R_{m}\right)-R_{f}\right]
$$

As a highly-levered firm, a bank has to incorporate in its loan pricing, other riskrelated costs for example, tax and bankruptcy cost. Bankruptcy costs will arise if 
a bank indulges in excessive risk-taking lending or trading. Thus, risk increases if debt to equity ratio increases for a bank. Incorporating the leverage effect (Hamada op cit.) into Equation (2), beta of an individual bank, $\mathrm{j}$, with loan capital can be expressed as:

$$
\beta_{\mathrm{jL}}=\beta_{\mathrm{ju}}\left[1+\mathrm{D} / \mathrm{E}_{\mathrm{j}}(1-\mathrm{tc})\right]
$$

where, $\beta_{\mathrm{jL}}=$ beta of levered firm, $\beta_{\mathrm{jU}}=$ beta of unlevered firm, $\mathrm{D} / \mathrm{E}=$ debt-equity ratio, tc $=$ tax rate applicable to income streams of a bank. A banking firm's risk increases as leverage increases. Thus, capital structure is likely to affect credit risk.

\subsection{Review of Empirical Literature}

Two strands in the literature on bank credit risk continue to receive increasing attention. One strand appears to suggest internal variables as potential determinants of risk measured as the unsystematic risk (see Hassan, 1993; Brewer et al., 1996; Gallo et al., 1996; Berger and DeYoung, 1997; Angbazo, 1997). The other strand highlights changes in external variables in the financial markets, regulations and economic conditions as affecting the systematic bank risk (Hassan et al., 1994; Corsetti et al., 1998). Both streams provide evidence of significant relationships among the internal variables, external factors and bank risk.

Chang (2001) claims that there exists a confusion as to what causes crises in emerging markets and states that the knowledge about crises in emerging markets is inadequate for analyzing risk in recent banking crises. He cites that one of the causes was the maturity mismatch: short-term international liabilities as shown by short-term foreign debts exceeding short-term international reserves. Table 2 provides statistics relating to the maturity position of five Asian economies. The statistics suggest that Indonesia and South Korea had this mismatch providing a huge build-up of risk as far back as 1990. June 1997 saw Thailand facing a very high risk in this regard, and the market participants' trading action, given this very dangerous development, led to a fall in currency first in Thailand, then Korea and elsewhere as contagion. Thus was born the 1997-8 Asian crisis.

Kraft and Jankov (2005) find that in Croatia, rapid loan growth increased the probability of credit quality deterioration and perpetrated the current account

Table 2: Asean 5: Short-term Foreign Debt/International Reserves

\begin{tabular}{|c|c|c|c|c|c|}
\hline & Inilnesin & Sorfuh Ko.tan & Mnlyin & Philipgines & Thrillmd \\
\hline June 1990 & 221 & 1.06 & 0.22 & 3.18 & 0.59 \\
\hline Jom 1994 & 1.73 & 1.61 & 0.25 & 0.41 & 0.99 \\
\hline Jne 1997 & 1.70 & 206 & 0.61 & D.95 & 1,45 \\
\hline
\end{tabular}


and foreign debt problems. Rapid loan growth takes place during economic boom times and such lending booms have been identified as a significant factor that increases the risk of a crisis (Caprio and Klingebiel, 1996). Ariff and Marisetty (2001) indicate that GDP is negatively related to bank risk in a study covering OECD and Asian countries. Similar negative relationship between GDP and credit risk of commercial banks was also obtained by Fischer, Gueyie and Ortiz (2002) in the U.S. and Canada. GDP is also significantly negatively related to credit risk of banks in Malaysia (Ahmad, 2003).

As to bank-specific credit risk determinants, a recent study by Jimenez and Saurina (2004) in Spain show that collateralised loans have a higher probability of default .They find that banks, whose probability of loan defaults is protected by collateral, have less incentives to undertake adequate screening and credit assessment at the time of loan approval. Type of loan is also a significant determinant of credit risk where loans given by saving banks are riskier and are prone to default. A close bank-to-borrower relationship is also found to be significantly positively related to credit risk where this relationship increases the banks' willingness to take more credit risk by lending to riskier firms.

Galloway et al. (1997) used standard deviation of weekly share returns as a proxy for bank risk while market to book value, operating leverage, capital, real size and HIGHRISK, a dummy variable, were five independent criterion variables used. The study shows that capital is significantly negatively related to risk. Size (measured by market value of equity) is positive and is significantly related to risk during the regulatory period but is negatively significant during a deregulatory regime when restrictions were imposed on banks following the failure of too-bigto fail policy. In contrast, Gallo, Apilado and Kolari (1996) find no significant relation between leverage and risk.

Berger and DeYoung (1997) find Lagged Capital (measured by equity capital to total assets) shows mixed results for different types of banks. In the case of thinly capitalized banks, the coefficient of Lagged Capital is significantly negatively related to credit risk. This finding supports the moral hazard hypothesis, and suggests that, on an average, thinly capitalized banks take more risky loans, which potentially could lead to higher problem loans. However, for all-banks sample, Lagged Capital coefficient is positive and significant. The researchers suggest that a possible reason could be that banks may raise the capital in advance to provide a cushion against possible loan loss arising from NPL increases. Shrieves and Dahl (1992) also find similar result but Cummins and Sommer (1995) discover an inverse relationship between capital asset ratio and credit risk. This finding suggests that better capitalized banks take more risk.

Further evidence of the impact of credit risk on bank performance is shown by Angbazo (1997). In this study, banks with a larger risky loan portfolio appear to require higher net interest margin to compensate the higher risk of default. This result suggests the significant relationship between net interest margin and 
credit risk. The findings of Hassan, et al. (1994) support the earlier findings that Size and Diversification are negatively related to risk. Brewer et al. (1996) find that loan sectors have a significant association with risk. Fixed-rate mortgage loans, investment in service corporations and real estate loans are found to be significantly negatively related to credit risk. However, non-fixed rate mortgage loan is significant and positively related to risk.

Bikker and Metzemakers (2004) investigated how bank provisioning behavior is related to business cycle. They find that banks make substantially higher provisions against potential loan loss or higher credit risk when GDP growth is low. Thus, higher provision indicates higher credit risk potentials. All macroeconomic variables tested (GDP growth, loan growth, and bank specific factors such as loan loss provision to total assets, earnings before tax and provision, loan to total assets and capital to total assets) are significant determinants of loan loss provisions.

Ahmed et al. (1998) find loan loss provision (LLP to total asset) to be positively significantly associated with NPL. Hence, a higher LLP indicates an increase in credit risk and deterioration in loan quality. Fisher, Gueyie and Ortiz's (2002) study of banks in NAFTA countries finds similar results with LLP positively related to risk Despite being in a different economic setting or stage of development or banking system, the Malaysian banks exhibit similar results where their LLP is positively and significantly related to credit risk (Ahmad, 2003).

Fisher, Gueyie and Ortiz (2002) find that, in Canada and Mexico, leverage is significantly positively related to bank risk. In contrast, Galloway, Lee and Roden, 1997 find mixed results for the U.S. Operating leverage is positively related to risk in pre-deregulatory period; negatively in de-regulatory periods. However, it is significantly positively related to risk in post-deregulatory or re-regulation periods. Fisher, Gueyie and Ortiz (2002) and Hassan et al. (1994) find that bank size (measured by natural logarithm of total assets) is significantly negatively related to risk of U.S. banks.

\section{Data, hypotheses and methodology}

\subsection{Data}

We use cross-sectional data of individual bank balance sheet and income statement items of commercial banks of selected countries. Besides being in different economic settings, these countries are chosen because they operate under different banking systems and market structures. The data for the analysis is obtained from The Bankscope data stream at the Monash University. We employ data of commercial banks only to obtain a more homogeneous group of financial institutions. The annual date pertain to the years in the study period stated previously.

The major hypothesis is that the literature-based eight factors will be highly correlated with credit risk of banks in each of the nine economies, more so in 
emerging economies. Next, we predict (since ours is large comparative study with all factors) that only a sub-set of the eight factors will be significant in a given economy. Third, we expect more factors in emerging economies and fewer factors in developed economies will be relevant to risk.

\subsection{Variables}

The dependent variable is changes in impaired loan (or non-performing loans) to total gross loans as a measure for credit risk. The independent variables are bank-specific factors are: management efficiency, loan-loss provision, loanto-deposit ratio, leverage, regulatory capital, funding costs, liquidity, spread and total assets. The definitions of each variable for hypotheses testing are shown in Table 3.

Table 3: Definitions of Independent Variables

\begin{tabular}{|c|c|}
\hline Veriables & Deffintrions: \\
\hline II & 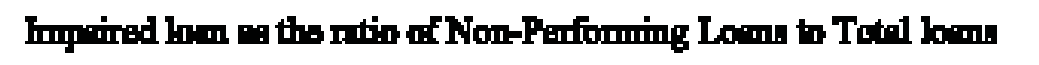 \\
\hline MGT & Bomings enow Total anest \\
\hline LEV & Total linbilition Totol A Anets \\
\hline REGCAP & Ther-1 capital /Total Loane \\
\hline LIP & 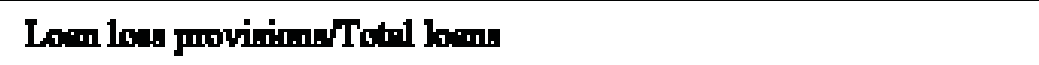 \\
\hline FCOST & 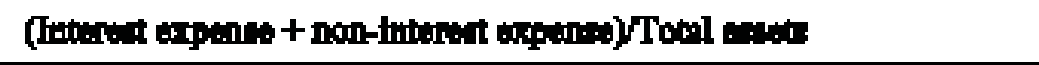 \\
\hline SPREAD & 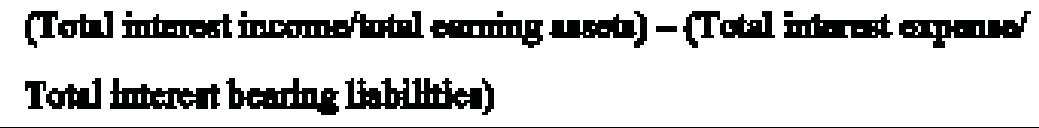 \\
\hline $\begin{array}{l}\text { LNTA(cumency } \\
\text { billon) }\end{array}$ & Nutmel log of trall ansoth \\
\hline LD & Total lonov (Time Deporitu). \\
\hline
\end{tabular}

\subsection{The Model}

The equation for the full model used in this study is:

$$
\begin{aligned}
& \mathrm{CR}_{\mathrm{it}}=\lambda_{0}+\lambda_{1} \mathrm{MGT}_{\mathrm{i}, \mathrm{t}}+\lambda_{2} \mathrm{LLP}_{\mathrm{i}, \mathrm{t}}+\lambda_{3} \mathrm{LD}_{\mathrm{i}, \mathrm{t}}+\lambda_{4} \mathrm{LEV}_{\mathrm{i}, \mathrm{t}}+ \\
& \lambda_{5} \operatorname{REGCAP}_{\mathrm{i}, \mathrm{t}}+\lambda_{6} \mathrm{FCOST}_{\mathrm{i}, \mathrm{t}}+\lambda_{7} \mathrm{LIQ}_{\mathrm{i}, \mathrm{t}}+\lambda_{8} \operatorname{SPREAD}_{\mathrm{i}, \mathrm{t}}+ \\
& \lambda_{9} \operatorname{LNTA}_{\mathrm{i}, \mathrm{t}}+{ }_{-\mathrm{i}, \mathrm{t}}
\end{aligned}
$$

The dependent variable, $\mathrm{CR}_{\mathrm{it}}$, is theimpaired loans or the ratio of non-performing loans to total loans as at the end of financial year of bank $\mathrm{j}$ in time $t$. The definitions of the eight independent variables are as stated in Table 3. Multi-country data items are standardized by the developers of the Bankscope database and, therefore, the variables are similarly defined across all countries. 


\subsection{Treatment on econometric issues}

In order to ensure that all regression assumptions are met, each variable is tested for linearity and normality: see tables 4 and 5 . Initial tests indicate that the variables are heteroscedastic and some variables are non-linear. Following Hair et al. (1998: 75), heteroscedaticity and non-linearity are corrected through data transformation. Thus, all variables were transformed into first level differences to ensure that the variables are homoscedastic. Correlation analysis and collinearity diagnostic were then carried out to assess the extent of multicollinearity among independent variables. This problem is detected using Variance Inflation Factor (VIF) with a cut-off threshold of 10 and tolerance value of 0.1: (See Hair et al. 1998: 193). Variables with large VIF values are excluded.

The results of collinearity diagnostics and normality tests for each country's test model are in tables 4(a) to (f). Table 5 shows no multi-collinearity problem between the risk predictors and no violation of normality assumption. This enables us to proceed with identifying the key credit risk and total risk determinants of deposit-taking institutions in the selected countries. All independent variables are regressed against credit risk proxy for the whole model. Subsequently, using AIC criterion within the stepwise regression procedure, a parsimonious model was identified and thus we determine key credit risk predictors for each country. All estimates are based on generalized least square regressions after corrections for heterokedasticity using White Heteroskedastiity Consistent Standard Errors and Covariance technique in Eviews programs.

\section{Analysis of Results}

\subsection{Descriptive Statistics}

Table 6 reports a summary of descriptive statistics of credit risk determinants. As for credit risk level, Thailand recorded the highest credit risk of 18.66 per cent over the study period. The next highest credit risk is for banks in Malaysia $(10.03 \%)$. This finding appears to show that Thailand and Malaysia incurred credit risk level about 9 times and 5 times respectively higher than the 2 per cent, which is the international standard. The acceleration in credit risk in these two countries is also attributable to the 1997 Asian Financial Crisis. The other countries in our sample such as Korea experienced a lower level of mean credit risk of 3.5 percent and 4.5 percent respectively. Mexico and France recorded higher mean credit risk level of 5.1 percent and 4.8 percent respectively. Table 6 and Figure 1 highlights the significant differences in the mean credit risk between the two economic regions, where lower credit risk is shown for developed economies, notably the U.S.

Statistics in Table 6 shows that most banks both in emerging and developed countries maintain a mean proportion of earning assets to total assets (MGT) of 65 percent. This suggests that the banks had two-thirds of their asset portfolio in interest-bearing, interest rate sensitive assets. The earning assets to total assets 
ratio reflects a bank's management efficiency in managing its assets to earn interest income (Angbazo, 1997). It is postulated that the higher the ratio the higher would be the management efficiency in generating interest income, and the lower is the credit risk. Malaysia's ratio of 65 per cent was within the international norm.

Table 4: Multicollinearity diagnostic statistics

\begin{tabular}{|c|c|c|c|c|c|}
\hline \multicolumn{3}{|c|}{ TWh 4(D) THAILAKD } & \multicolumn{3}{|c|}{ Tabla 4(b) KOAEA } \\
\hline Indoundark & Toloringes & VIF & Lapood ax & Tolorimed & VIF \\
\hline 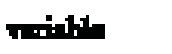 & Valte & & mistull & piter & \\
\hline Mcr & $0.7 \% 3$ & 1261 & MCT & 0.090 & 1.005 \\
\hline $\mathbf{L} \mathbf{P}$ & 0.74 & 1.400 & $\mathbf{H F}$ & o.945 & 1.058 \\
\hline $\mathbf{L}$ & $02 \pi$ & 3.701 & $\mathbf{L}$ & 0.907 & 1.100 \\
\hline LEV & 0.414 & 2415 & LEV & D.861 & 1.041 \\
\hline MECTCAP & a.s & 1.490 & RECCAP & 0.958 & 1.049 \\
\hline FCOST & $\mathbf{0 . 6 0 2}$ & $1 \leq x 4$ & FCOST & osiz & 1.018 \\
\hline L⿳㇒⿴囗十 & 0.558 & 1.819 & IPQ & 0.867 & 1.154 \\
\hline SFREAD & a.t. & 1.302 & gPसAD & 0.992 & 1.008 \\
\hline IxTh & a.ess & 1.497 & LNTh & 0.954 & 1.04 \\
\hline \multicolumn{3}{|c|}{ Tuble 4(c) M(4) } & \multicolumn{3}{|c|}{ TWb 4(d) NEXICO } \\
\hline bilependent & Toleanes & $\mathbf{Y I F}$ & Findepentilet & Tolertenes & vIF \\
\hline Vxinhl- & Valpe & & mistall & wate & \\
\hline MGT & 0.646 & $1 \leq 49$ & MCT & A.44 & 2274 \\
\hline LIF & 0.61 & 1,40 & LIP & 0.597 & 1.675 \\
\hline $\mathbf{L D}$ & a.tsos & 1370 & LD & 0.616 & 1.024 \\
\hline LEY & a 468 & 2.172 & LEY & DE1 & 1.448 \\
\hline METCAP & 0.500 & 2000 & $\mathrm{BFCCAP}$ & 0.515 & 1 s) \\
\hline FCOST & 0.6s: & 1518 & Fcost & 0.65 & 1520 \\
\hline $\mathbf{L X}$ & a.trt & 1.139 & LER & 0,24 & 1.800 \\
\hline SFREAD & a.รI & 1318 & GPJAD & D809 & $1 . x 6$ \\
\hline Lith & a.tis & 1282 & LNTh & 0.51 & $1 s \mathbf{s}$ \\
\hline \multicolumn{3}{|c|}{ T-1.16 4(b) JAPAN } & \multicolumn{3}{|c|}{ 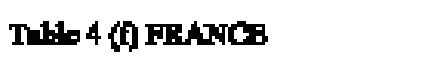 } \\
\hline Badependent & 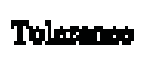 & VIF & Findepenterit & Tolertect & vाF \\
\hline & Valho & & 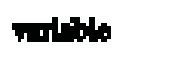 & rito & \\
\hline MGT & a.ss & 1.007 & MGT & 688 & 1.137 \\
\hline LIP & 0.645 & 1347 & LIP & 050 & 1.039 \\
\hline LD & a.sss & 1501 & LD & 0.214 & $1 \geqslant 0$ \\
\hline LEY & 0211 & 4.750 & LEY & 0.475 & 2.107 \\
\hline REGCAF & a.1. & 1340 & RECCAP & 0.651 & 1313 \\
\hline PCOST & 0.715 & 1274 & FCo:sT & 0.76 & 1.313 \\
\hline LX) & a.ts & 1.160 & LEQ & 0.78 & 1 Iro \\
\hline
\end{tabular}


Figure 1:Credit Risk: Multi-country Comparison (1996-2002)
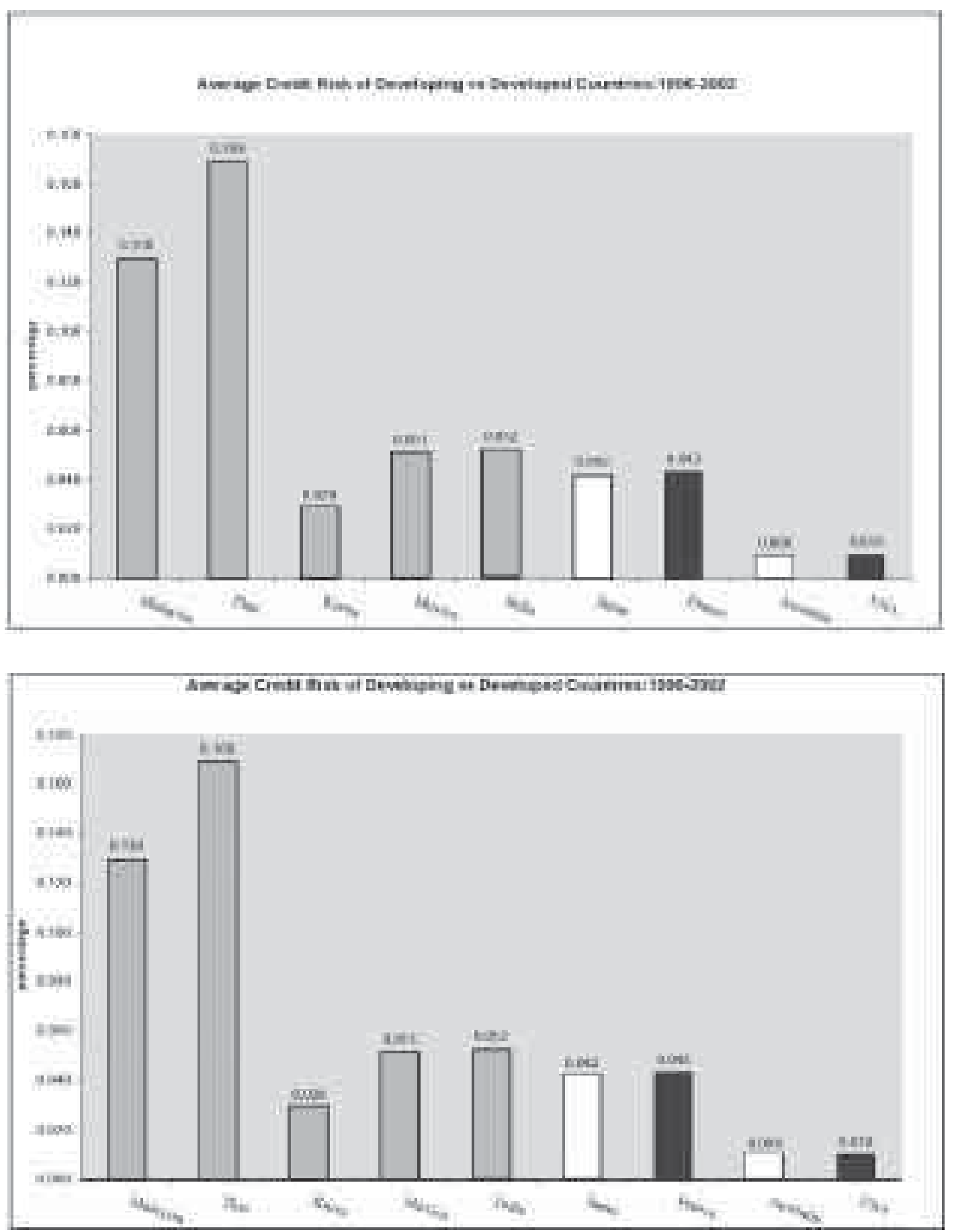

Banks in Korea and Thailand maintained a mean loan loss provision (LLP) of about 2 percent per annum. This shows as a common practice among most emerging country banks. However, banks in France and Mexico show a higher mean LLP ratio of 3 percent. Judging from the lower credit risk experienced by banks in these two countries, the higher LLP ratio suggests a more prudent loan loss provisioning policy adopted by the French and Mexican banks over the study period. The U.S. banks maintained a much better mean LLP of 1.13 percent, 
Figure 2: Bank spread: multi-country comparison

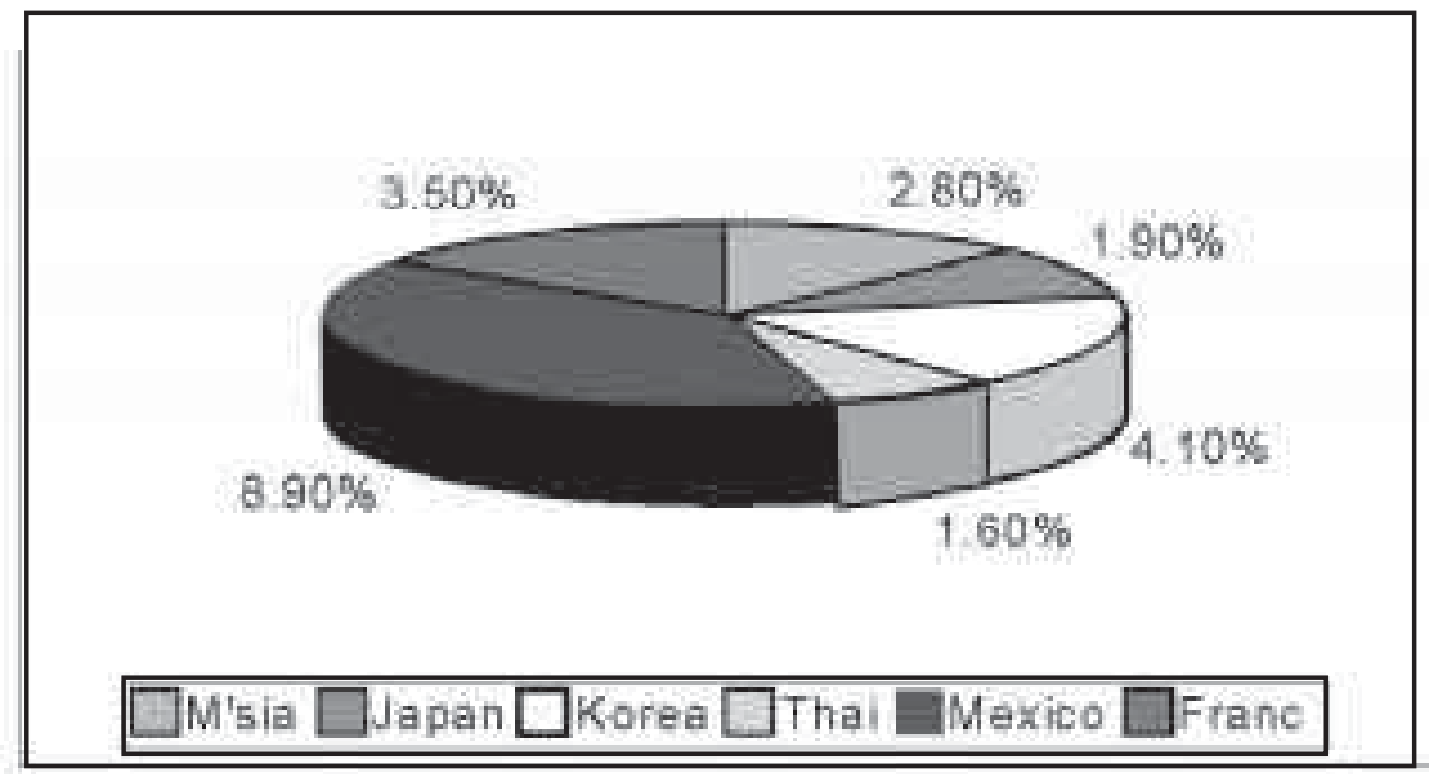

Table 5: Diagnostic statistics on normality

NORMALITY TEST RESULTS - SHAPIRO-WILK TEST

\begin{tabular}{|c|c|c|c|c|c|c|c|c|c|}
\hline & 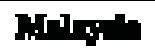 & Thent & Name & In & Trd & ט"st & סירד & D.X. & 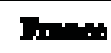 \\
\hline \multirow[t]{2}{*}{$c x$} & a.s5st & $0 \leq 850$ & 0.2548 & 0.8950 & 8.0020 & 0.290 & 0.7450 & a.sent & $0,0=00$ \\
\hline & & & $(0,000)$ & (0000) & $(0,000)$ & & & & ת0000 \\
\hline \multirow[t]{2}{*}{ MOT } & $0.0 \%$ & 05020 & 0.74 & 0.3100 & 0.5460 & 0.460 & 0.4500 & 0.3990 & 0.4930 \\
\hline & (4000) & (0000) & $(0,0000)$ & (0000) & (0.000) & $(0.0000)$ & (000000 & $(0,000)$ & (00000) \\
\hline \multirow[t]{2}{*}{ LIP } & 0.9000 & 0.7110 & 0.2920 & 0.2150 & 0240 & 0.2650 & 0.0200 & 0.2210 & 0.1650 \\
\hline & (10000) & (00000) & $(0,0000)$ & (00000) & $(0.0000)$ & $(0.0000)$ & (00000) & $(00000)$ & $(000000$ \\
\hline \multirow[t]{2}{*}{ Ln } & 0.9350 & 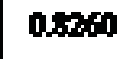 & 0.9160 & 0.4800 & 0.0640 & Q_B68 & 08170 & a.sio & 0.6000 \\
\hline & (coosid) & (0000) & $(0,0000)$ & (00000) & $(00000)$ & $(00000)$ & (000) & $(0,000)$ & (100000) \\
\hline \multirow[t]{2}{*}{ LEY } & 0.5710 & $0 \leq 5130$ & 0.642 & 0,870 & 05140 & 0.4190 & 0.4020 & 0.3680 & 05110 \\
\hline & (10000) & (00000) & $(0,0000)$ & (00000) & $(0.0000)$ & $(0.0000)$ & 00000 & $(0.0000)$ & $(00000)$ \\
\hline \multirow[t]{2}{*}{ DERCAP } & 0.560 & 03470 & 0.676 & 0.5230 & OAORO & 0.3400 & 09590 & 0.5670 & 0.6480 \\
\hline & (20000) & poons & $(0,0000)$ & (0000) & $(0,0000)$ & (20000) & (0000) & (20000) & (100000) \\
\hline \multirow[t]{2}{*}{ FCost } & 0.9160 & 02000 & 0.6910 & 0.550 & 0.9990 & 0.440 & $0.4 \% 10$ & 0.690 & 0.8170 \\
\hline & (60000) & (00000) & $(0,0000)$ & $(00000)$ & $(00000)$ & $(00000)$ & (00000) & $(0.0000)$ & 00000 \\
\hline \multirow[t]{2}{*}{ LE } & 0.960 & 09520 & 0.004 & 0.760 & 0.7990 & $0.7 \%$ & 0.4380 & 0.7540 & 0.7600 \\
\hline & (0.0\%) & 00000 & (0.0000) & $(00000)$ & (00000) & $(0.0000)$ & 0.0000 & $(0,0000)$ & 0.0000 \\
\hline \multirow[t]{2}{*}{ STREAD } & ants & 0.1160 & OAS1 & 0.700 & $0.91 \%$ & 0.2190 & 0.8120 & 0.5600 & 0.4970 \\
\hline & $(2000)$ & (00000) & $(0.0000)$ & (00000) & $(0.000)$ & $(0.0000)$ & 00000 & (5.0000) & (0000) \\
\hline \multirow[t]{2}{*}{ LNT } & enos & $0 \leq x+0$ & tastot & $0.58 \%$ & an: & 0.00 & arro & $\cos 00$ & 06850 \\
\hline & (40) & (0000) & $(0,0000)$ & (0000) & $(0.000)$ & (0000) & (000) & (c000) & $(00000)$ \\
\hline
\end{tabular}


Table 6: Descriptive statistics of the nine variables entering the regression tests

\begin{tabular}{|c|c|c|c|c|c|c|c|c|c|c|c|c|c|c|c|}
\hline \multicolumn{16}{|c|}{ REGION 1(Developing Courtries) } \\
\hline & & m'sia & & & korea & & mexico & & & & india & & & thai & \\
\hline & meat & median & stod dev & mean & median & std dey & mean & mediati & $\operatorname{sid} d d v$ & meärn & $\begin{array}{l}\text { nedia } \\
17\end{array}$ & std dev & mean & median & std dev \\
\hline $\mathrm{CR}$ & 0.1296 & 0.1035 & 0.1473 & 0.6287 & 0 & 0.0552 & 0.0511 & 0.014 & 0.1665 & 0.0524 & 0.0515 & 0.00503 & 0.1689 & 0.0943 & 0.2686 \\
\hline MGI & 0.6395 & 0.6402 & 0.0226 & 0.5114 & 0.629 & 0.248 & 0.5431 & 0.6032 & 0.1489 & 0.644 & 0.6583 & 0.0677 & 0.5154 & 0.6504 & 0.2633 \\
\hline LLP & 0.0111 & 0.0124 & 0.0037 & 0.0168 & 0.009 & 0.0274 & 0.0315 & 0.0083 & 0.099 & $0.010^{\circ}$ & 0,009 & 0.0567 & 0.0167 & 0.0059 & 0.1054 \\
\hline LD & 0,5757 & 0.589 & 0.0748 & 0.6786 & 0.6464 & 0.53 & 0.6707 & 0.6851 & 0.3553 & 0.5898 & 0.5304 & 0.3893 & 0.4758 & 0.5788 & 0.3097 \\
\hline I.EV & 0.5028 & 0.4926 & 0.1654 & 0.5503 & 0.6685 & 0.2884 & 0.5783 & 0.6353 & 0.1449 & $0.654^{\prime \prime}$ & 0.6681 & 0.0617 & 0.5034 & 0.6588 & 0.288 \\
\hline REGCAP & 0.1355 & 0.1249 & 0.1011 & 0.0759 & 0,0685 & 0.105 & 0.3279 & 0.1743 & 0.4097 & 0.1479 & 0.1077 & 0.1786 & 0.1042 & 0.0681 & 0.2169 \\
\hline $\mathrm{FCOST}$ & 0.0501 & 0.0400 & 0.0147 & 0.0995 & 0.0615 & 0.2429 & 0.2029 & 0.1751 & 0.1561 & 0.0708 & 0.073 .1 & 0.0744 & 0.0545 & 0.0502 & 0.0394 \\
\hline LIQ & 0.014 & 0.0136 & 0.0065 & 0.1073 & 0.8509 & 0.0666 & 0.3163 & 0.2554 & 0.2739 & 0.3778 & 0.3372 & 0.1257 & 0.1082 & 0.0952 & 0.1003 \\
\hline SPRFAD & 0.0297 & 0.0297 & 0.014 & 0.0335 & 0.0231 & 0.1366 & 0.1075 & 0.0679 & 0.2717 & 0.0284 & 0.6299 & 0.9157 & 0.0127 & 0.0156 & 0.0176 \\
\hline I_NTA & 16.8145 & 16.6577 & 0,8528 & 1.9300 & 2.397 & 0.9493 & 10.2572 & 9.7297 & 3.3344 & 2.4385 & 2.577 & 0.1404 & 5.5090 & 5.6963 & 1.3739 \\
\hline \multicolumn{16}{|c|}{ REGION 2 (Developed Countries) } \\
\hline & $\begin{array}{l}\text { dustralia } \\
\text { mean }\end{array}$ & median & stad dev & man & mapan & stod dev & mean & $\begin{array}{l}\text { USa } \\
\text { meqdiat } \mathrm{s}\end{array}$ & std dew i & mean & $\begin{array}{l}\text { france } \\
\text { median }\end{array}$ & std dev & & & \\
\hline $\mathrm{CR}$ & 0.0091 & 0.0003 & 0.0368 & 0.0419 & 0.0351 & 0.0489 & 0.0096 & 0.0057 & 0.0154 & 0.0431 & 0.0000 & 0.0663 & & & \\
\hline MGT & 0.5778 & 0.6627 & 0.2165 & 0.5782 & 0.6701 & 0.2278 & 0.6086 & 0.6448 & 0.1390 & 0.5752 & 0.6457 & 0.2015 & & & \\
\hline LLP & -0.0011 & 0.0013 & $0.023\}$ & 0,0103 & 0.0070 & 0.0102 & 0.0113 & 0.0040 & 0.0542 & 0.0298 & 0.0063 & 0.1533 & & & \\
\hline LD & 0.7410 & 0.8484 & 0.0233 & 0.5934 & 0.6134 & 0.2953 & 0.6400 & 0.6089 & 0.3351 & 0.8208 & 0.5881 & 0.0543 & & & \\
\hline LEV & 0.5928 & 0.6612 & 0.2027 & 0.5900 & 0.6708 & 0.2208 & 0.6090 & 0.6479 & 0.1373 & 0.5745 & 0.6538 & 0.2038 & & & \\
\hline REGCAP & 0.0814 & 0.0683 & 0.1266 & 0.0510 & 0.0524 & 0.0269 & 0.1664 & 0.1290 & 0.1483 & 0.2250 & 0.1280 & 0.2978 & & & \\
\hline $\mathrm{F} \cos \Gamma$ & 0.0561 & 0.0538 & 0.0500 & 0.0167 & 0.0142 & 0.0191 & 0.0426 & 0.0419 & 0.0183 & 0.0559 & 0.0502 & 0.4000 & & & \\
\hline LIQ & 0.0742 & 0.0527 & 0.0825 & 0.13 .40 & 0.1200 & 0.1545 & 0.1073 & $0.06 \% 7$ & 0.1513 & 0.1199 & 0.0467 & 0.1634 & & & \\
\hline SPREAD & -0.1516 & -0.0225 & 0.6620 & 0.0168 & 0.0194 & 0.0079 & 0.0415 & 0.0408 & 0.0289 & 0.0316 & 0.0222 & 0.0834 & & & \\
\hline $\begin{array}{l}\text { LNTA } \\
\mid\end{array}$ & 2.0081 & 2.2541 & 0.7607 & 6.7771 & 7.4380 & 2.7902 & 2.0717 & 2.1779 & 0.5039 & 1.8910 & 2.0594 & 0.6761 & & & \\
\hline
\end{tabular}

which appears to be consistent with its low credit risk level $($ mean $=0.0096)$. Malaysia and Japan are noted to have a 1 percent mean LLP although the mean credit risk is higher (Malaysia $=10 \%$; Japan $=4 \%$ ).

The analysis further highlights that Mexican banks earned a spread of an average of 8.96 per cent, which is the largest spread in our sample. In contrast, Thailand banks recorded the smallest spread of an average 1.6 per cent during the study period. Figure 2 illustrates the mean spreads of banks in some of the countries in the sample: Malaysia (2.8\%), Japan (1.9\%), Korea (4.1\%), Thailand (1.6\%), Mexico (8.9\%) and France (3.5\%).

Table 6 highlights that the variable with the largest standard deviation among banks is the leverage. This is noted in Malaysia, Mexico, Japan and France. The standard deviation in funding cost (defined as total interest expenses plus noninterest expenses to total assets) is noted also as highest among Korean banks although the mean funding cost is highest for banks in Mexico (20.2\%). This suggests marked differences in operating costs levels among Korean banks.

\subsection{Regression results on credit risk determinants}

The statistics in Table 7 suggest a set of important credit risk determinants across the 9 countries based on the results prior to a search for a parsimonious model: Table 8 is from the parsimonious model identification using AIC. Based on the R-squared statistics, the best accountability for the variations in credit risk is found for Mexico, Malaysia and Australia with adjusted R-squared values $0.5190,0.3427$ and 0.3632 respectively. The model fit is good as indicated by the F-ratio obtained (not shown). Several variables emerge as significant determi- 
nants of credit risk of commercial banks, despite some differences in credit risk determinants across countries.

MGT (denoted by earning assets to total assets ratio) is significantly related to credit risk of banks in three countries, Malaysia, India and France. The positive signs of this coefficient for Malaysia (1.3454 with $\mathrm{t}=2.6485)$ and France $(0.0627$ with $\mathrm{t}=8.2478)$ suggest that the higher the proportion of earning assets (which largely consist of loans) the greater is the tendency for banks in these countries to incur potentially high credit risk. Conversely, MGT is significantly negatively related to credit risk of banks in India. The possible explanation for this obverse finding could be that the earning assets of the banks during the test period comprised more interest-earning assets other than loans such as investment securities and incomes from dealing in securities, which did not incur any non-performing incidence or high default rates. That is plausible given the more oligopolistic banking structure in that country with very large banks acting as allpurpose banks, although these banks are commercial banks. Hence, the higher the bank's earning assets the lower would be their credit risk. The negative relationship between MGT and credit risk supports the findings of Angbazo (1997).

Loan loss provisions to total loans (LLP) is significantly positively related to credit risk of banks in Australia, Japan, Mexico and Thailand,. The results indicate that higher LLP ratio signals potentially higher credit risk as banks need to

Table 7: Credit Risk determinants, whole model, for developed and developing economies

The test model is: $\mathrm{CR}_{\mathrm{it}}=\lambda_{0}+\lambda_{1} \mathrm{MGT}_{\mathrm{i}, \mathrm{t}}+\lambda_{2} \mathrm{LLP}_{\mathrm{i}, \mathrm{t}}+\lambda_{3} \mathrm{LD}_{\mathrm{i}, \mathrm{t}}+\lambda_{4} \mathrm{LEV}_{\mathrm{i}, \mathrm{t}}+\lambda_{5} \mathrm{REGCAP}_{\mathrm{i}, \mathrm{t}}+$ $\lambda_{6} \mathrm{FCOST}_{\mathrm{i}, \mathrm{t}}+\lambda_{7} \mathrm{LIQ}_{\mathrm{i}, \mathrm{t}}+\lambda_{8} \mathrm{SPREAD}_{\mathrm{i}, \mathrm{t}}+\lambda_{9} \mathrm{LNTA}_{\mathrm{i}, \mathrm{t}}+\varepsilon_{\mathrm{i}, \mathrm{t}^{*}}$

The variables are defined in Table 3 . Of the eight independent variables, the dependent variable, credit risk of commercial banks in the named economies, is significantly correlated with a number of risk factors.

\begin{tabular}{|c|c|c|c|c|c|c|c|c|c|}
\hline & Malaysia & Korea & Mexico & India & Thai & Australia & Japan & USA & France \\
\hline \multirow[t]{2}{*}{ MGT } & 1.3764 & 0.0775 & -0.0898 & -0.1193 & -0.0352 & -0.0095 & 0.0171 & $\quad 0,0436$ & 0.0816 \\
\hline & $(2.2054)^{* *}$ & $(3.2487)^{* * *}$ & $(-1.6411)$ & $(-2.0812)^{* *}$ & $(-0.1888)$ & $(-0.2891)$ & -1.2927 & $(2.1842)^{* *}$ & -1.6493 \\
\hline \multirow[t]{2}{*}{ LLP } & -0.9943 & 0.5122 & -1.1863 & 0.0642 & 0.2745 & -1.3053 & 2.0382 & .0 .0077 & -0.0534 \\
\hline & $(-0.2489)$ & -1.4333 & $(2.632$ & -1.2599 & $(1.9349)^{*}$ & $(-2.0347)^{* *}$ & $(8.3983)^{* * *}$ & $(-0.6469)$ & $(-1.4546)$ \\
\hline \multirow[t]{2}{*}{ LD } & 5233 & 0103 & & -0.0226 & -0.197 & 0.001 & -0.0254 & 0.0101 & 0.0587 \\
\hline & $51\}^{* *}$ & $(1.7754)^{*}$ & $(-1.6875)^{*}$ & $(-1.6624)^{*}$ & $(-1.5104)$ & $(0.1882)$ & $(-1.1968)$ & (1.5450) & $(2.9426)^{* * *}$ \\
\hline \multirow[t]{2}{*}{ LEV } & & -0.0442 & 0.1935 & 0.0311 & 0.2388 & 0.0059 & 0.2325 & -0.0468 & -0.0935 \\
\hline & $(-1.5175)$ & $(-1.1293)$ & $(3.0775)^{* * *}$ & -0.4689 & $(1.7503)^{*}$ & $(-0.3459)$ & $(3.3364)^{* * *}$ & $(-1.2437)$ & $(-0.9254)$ \\
\hline \multirow[t]{2}{*}{ REGCAP } & 0.7704 & 0.0090 & $0.123 !$ & -0.0667 & -0.0586 & $(0.1413)$ & 0.6403 & 0.0094 & -0.0042 \\
\hline & $(2.2237)^{* *}$ & -1.1608 & $(2.3211)^{* *}$ & $(-2.6939)^{* * *}$ & $(-0.7356)$ & $(-1.726 .3)^{*}$ & $(4.3973)^{* * *}$ & $(1.0381)$ & $(-0.2688)$ \\
\hline \multirow[t]{2}{*}{ FCOST } & 639 & -0.0091 & -0.1656 & 0.2151 & 1.3905 & 1032 & 0.509 & 0.0619 & -0.1818 \\
\hline & $(0.2970)$ & $(-0.3691)$ & $(-1.1645)$ & $(1.7545)^{*}$ & $(3.2790)^{* * * *}$ & $(0.9663)$ & $(-5.6231)^{* * *}$ & $(0.9180)$ & $(-1.9046)^{*}$ \\
\hline \multirow[t]{2}{*}{ LIQ } & 3.1371 & 0.0417 & -0.1315 & 0.1092 & -0.0002 & 0.0966 & -0.0286 & 0.0405 & 0.0697 \\
\hline & $(1.0916)$ & $(2.6869)^{* * *}$ & $(-2.6333)^{* * *}$ & $(4.3150)^{* \star *}$ & $(+0.0009)$ & $(1.9475)^{*}$ & $(-3.6785)^{+++}$ & $(2.6979)^{+++}$ & $(2.1998)^{* *}$ \\
\hline \multirow[t]{2}{*}{ SPREAD } & 4836 & -0.0296 & -0.0524 & -1.1757 & -4.4726 & \begin{tabular}{|c|}
0.0018 \\
\end{tabular} & -2.5963 & -0.0231 & -0.1494 \\
\hline & $(0.2495)$ & $(-4.2223)^{* * * *}$ & $(-0.8081)$ & $(-4.1836)^{* * *}$ & $(-4.6176)^{* * *}$ & $(3.2697)^{* * *}$ & $(-2.2894)^{* * *}$ & $(-0.4123)$ & $(-1.6029)$ \\
\hline \multirow[t]{2}{*}{ LNTA } & -0.0847 & 0.0014 & 0.0011 & 0.0463 & 0.0273 & 0.0047 & -0.013 & -0.0005 & 0.012 \\
\hline & $(-0.3399)$ & -0.1665 & -0.5321 & $(2.3755)^{* *}$ & -1.8745 & $(0.5195)$ & $(-5.4667)^{* * *}$ & $(0.0627)$ & -0.9618 \\
\hline \multirow[t]{2}{*}{ C } & -0.8797 & 0.0000 & 0.0010 & 0.0005 & -0.0009 & -0.0015 & 0.10003 & -0.0014 & 0.0014 \\
\hline & $(-0.9444)$ & $(-0.0183)$ & -0.1929 & -1.2707 & $(-0.5485)$ & $(-0.8316)$ & -1.6101 & $(-1.9500) *$ & -0.5131 \\
\hline R SQ & 0.4285 & 0.1643 & 0.5314 & 0.3097 & $0.520 \%$ & 0.3880 & 0.273 & 0.1472 & 0.1957 \\
\hline ADI. R, SQ & 0.3427 & (1). 1413 & 0.5190 & 0.2934 & 0.4982 & 0.3632 & 0.2543 & 0.1287 & 0.1755 \\
\hline
\end{tabular}


make greater provisions against potentially greater non-performing loans. This finding is consistent with past findings (Ahmed et al. 1998; Fisher, Gueyie and Ortiz, 2002; Ahmad, 2003 and Bikker and Metzemakers, 2004).

The loans to deposit ratios (LD) predicts that the bigger the loan portfolio relative to deposit size the higher should be the probability of loan default. LD ratio is a significant positive determinant of credit risk in Malaysia, in the U.S., and France. However, contrary to theory and past evidence for different test periods, leverage (measured by total liabilities to total assets as used in many studies) is not a significant factor for credit risk formation in all countries except for Mexico in this study.

Another contrasting finding is that we find the coefficient estimate for liquidity ratio (LIQ) is significantly positively related to credit risk in several countries: Australia, India, Korea and the US. This finding suggests that the banks with more liquid assets tend to have higher credit risk. A possible explanation for this contrary-to-theory empirics is that banks are motivated to short term assets or lend by means of short-term interest rates to hold more liquid asset (especially in periods of crises) to ward off rapidly changing interest rate markets in crisis periods While the banks may earn higher income from converting these liquid assets into cash at higher rates, the high interest rates might cause many bank borrowers to experience cash flow problems, forcing them to default their loan repayments, thus increasing credit risk For Mexico, LIQ is significant but the coefficient is negative. The result in this situation suggests that the banks might have maintained a higher proportion of their funds in liquid assets, less fund to provide for loans. Thus, the banks might have potentially lower credit risk based on a smaller

Table 8: Credit Risk determinants in developing and developed economies - Parsimonious Model

\begin{tabular}{|c|c|c|c|c|c|c|c|c|c|c|}
\hline REGION 1: & DEVELOPING & ECONOMIES & & & & REGION 2 & DEVEOLPED & ECONOMIES & & \\
\hline & MALAYSIA & THAI & KOREA & MEXICO & IND/A & & USA & AUSTRALIA & FRANCE & \\
\hline MGT & $\begin{array}{l}1.3454 \\
(2.5485)^{n+*}\end{array}$ & & & & $\begin{array}{l}{[-0.7924)} \\
(-2.4878)^{* *}\end{array}$ & MGT & & & $\begin{array}{l}0.0627 \\
(8.2478)^{+\star \pi}\end{array}$ & \\
\hline LLF & & $\begin{array}{c}0.3246 \\
(2.0655)^{* *}\end{array}$ & & $\begin{array}{l}1.7899 \\
(2.7752)^{* \star \star}\end{array}$ & & L.LP & & $\begin{array}{l}(1.3034) \\
(-2.0515)^{* *}\end{array}$ & & $\begin{array}{l}1.8647 \\
(8.7439)^{* 4+4}\end{array}$ \\
\hline LEV & $\begin{array}{l}0.4387 \\
(2.4172)^{+*}\end{array}$ & & & $\begin{array}{r}0.1418 \\
(3.2712)^{*+*}\end{array}$ & & $\begin{array}{l}\text { LD } \\
\text { LEV }\end{array}$ & $\begin{array}{c}0.0090 \\
(2.3292)^{* * *}\end{array}$ & & $\begin{array}{l}0.0108 \\
(2.5547)^{2+*+}\end{array}$ & \\
\hline REGCAP & $\begin{array}{l}0.8623 \\
(2.3502)^{* *}\end{array}$ & & & $\begin{array}{l}0.1132 \\
(2.3527)^{\times 4}\end{array}$ & $\begin{array}{l}(0.1113) \\
(-3.4684)^{* * *}\end{array}$ & $R E G C A P$ & & $\begin{array}{l}(0.1384) \\
(-1.7342)^{x}\end{array}$ & & $\begin{array}{l}0.5453 \\
(6.3054)^{+ \pm=}\end{array}$ \\
\hline FCOST & & $\begin{array}{c}2.20555 \\
(2.5922)^{* * \hbar}\end{array}$ & & & & FCOST & & & & $\begin{array}{l}(0.3702) \\
(-3.5415)^{*+x}\end{array}$ \\
\hline L:O & & & $\begin{array}{l}0.1683 \\
(2.9811)^{\star \star \star}\end{array}$ & $\begin{array}{l}-0.1032 \\
(-2.3578)^{*}\end{array}$ & $\begin{array}{l}0.1365 \\
(5.1517)^{* * *}\end{array}$ & $L I Q$ & $\begin{array}{l}0.0415 \\
(2.7787)^{* \pm 1}\end{array}$ & $\begin{array}{l}0.1097 \\
(2.1108)^{*}\end{array}$ & & \\
\hline SPREAD & & $\begin{array}{l}(5.4449] \\
(-5.2840)^{\mathrm{n} *}\end{array}$ & & & $\begin{array}{l}-1.3053 \\
(-4.263\}^{+*+}\end{array}$ & SPREAD & & & $\begin{array}{l}(0.1186) \\
(2.2809)^{*+1}\end{array}$ & \\
\hline LNTA & & $\frac{0,0257}{(3.15 \overline{1})^{\cdots \cdots}}$ & & & & LNTA & & & & \\
\hline $\mathrm{c}$ & -1.1002 & $(0.0038)$ & 0.0019 & -0.0327 & 0.7865 & c & $(0.0006)$ & 0.0042 & $(0.0036)$ & 0.0010 \\
\hline & $(-2.8928)^{* *}$ & $(-0.5844)$ & $(0.6731)$ & $(-1.0026)$ & $(3.6473)^{\mathrm{max}}$ & & $(0.7913)$ & 0.8126 & $(-2,2570)^{* *}$ & $(0.2870)$ \\
\hline R.squared & 0.3822 & 0.3382 & 0.1415 & 0.5128 & 0.1733 & R.Squared & 0.1183 & 0.3825 & 0.0979 & 0.2313 \\
\hline Adj. Rsq. & 0.3541 & 0.3246 & 0.1363 & 0.5044 & 0.1631 & Aej, Rsa & Q. 1141 & 0.3716 & 0.0879 & 0.2248 \\
\hline No. obs & 70 & 200 & 334 & 294 & 331 & No. obs & 424 & 232 & 367 & 359 \\
\hline
\end{tabular}


loan portfolio. This could also be the banks' strategy to counter high problem loans incurred from the preceding years.

Spread emerged as a significant credit risk determinant. However, the evidence for the relationship between spread and credit risk in this study is mixed: negative for banks in India and Thailand but positive for banks in France. This inverse relationship implies that a bank that charges higher interest to its borrower to earn higher spread might deter less qualified borrowers (who are potential loan defaulters) to borrow, thus curtailing the banks' credit risk exposure.

Another key credit risk determinant common to many countries in the study is the regulatory capital. (The evidence on the impact of regulatory capital on credit risk is mixed as discovered by Berger and DeYoung, 1997.) For Japan, Malaysia, and Mexico, capital is significantly positively related to credit risk. This result would have us believe that banks would be required to increase their capital as a cushion to absorb potential losses that might arise from an increase in credit risk. For our test period, this is intuitively the response expected. Berger and DeYoung (1997) and Cummins and Sommer (1995) find the same result further, and rationalized that large banks are willing to take higher risk or lend to risky borrowers for lucrative returns because they have the capability to absorb the losses as they enlarge their capital. In contrast, the results for Australia and India suggest that under-capitalized banks take more risks, as the relationship between credit risk and regulatory capital is significant but negative. This finding is consistent with that provided in Shrieves and Dahl (1992), Park (1997) and Berger and DeYoung (1997).

\section{Conclusions}

This study investigated credit risk determinants across two types of banking systems. Although several studies on credit risk determinants have been conducted in the past, they are mostly confined to single country. Eight factors as potential risk determinants of credit risk of banks were incorporated in two test models to reveal which of the eight are major contributors of credit risk in emerging economy banking systems compared to those in developed economies. Our major findings can be summarized: anywhere from two to four factors are significant determinants of credit risk of any one banking system. We find regulatory capital is important for banking systems that offer multi products; management quality is critical in the cases of loan-dominant banks, example in emerging economies.

Contrary to theory and some earlier studies, we find leverage is irrelevant to credit risk of banks in several economies during our test period. An increase in loan loss provision consistently emerges, as in prior studies, to be a significant determinant of potential credit risk. This study also highlights that credit risk in emerging economy banks is higher than that in developed economies and that risk is formed by a larger number of bank-specific factors in emerging economies compared to their counterparts.

Acknowledgement: This article is an edited version of one of three best papers 
selected after blind review process at the $17^{\text {th }}$ FMA-Asian Finance Association Conference, Malaysia, 2005. We acknowledge the helpful comments of the Editor in revising this paper to this published version.

Author statement: Nor Hayati Ahmad is an Associate Professor at the University Utara Malaysia, Sintok, Kedah, Malaysia. Her teaching and research interests are in banking. Ariff holds a chair in Finance, Bond University, Australia, and his research interest is on Asian capital markets behaviour.

\section{References}

Ahmad, N.H., (2003). "Credit Risk Determinants: By Institutional Type", Proceedings of Malaysian Finance Association Conference, 2003.

Ahmed, A.S., C. Takeda and T. Shawn 1998. Bank Loan Loss provision: A reexamination of capital management, Earnings Management and Signaling Effects. Working paper, Department of Accounting, Syracuse University, 1-37.

Angbazo, Lazarus, (1997). "Commercial bank net interest margins, default risks, interest rate risks and off-balance sheet banking", Journal of Banking and Finance 2: 55-87.

Ariff, M. and Marisetty, V.B., (2001). "A New Approach to Modelling MultiCountry Risk Premium Using Panel Data Test Method", Proceedings of MFS Conference in Cyprus, 2003.

Berger, Allen N and DeYoung, Robert, (1997). "Problem Loans and Cost Efficiency in Commercial Banks", Journal of Banking and Finance 21: 849-870.

Brewer, E.III, Jackson, W. E.III and Mondschean, T.S., (1996). "Risk, regulation, and S \& L diversification into nontraditional assets", Journal of Banking and Finance 20: 723-744.

Caprio, G. Jr. and D. Klingebiel, (1997). "Bank Insolvency: Bad Luck, Bad Policy and Bad Banking", Michael Bruno and Boris Pleskonic, eds. Annual Bank Conference on Development Economic 1996, The World Bank.

Chang, Roberto, (2001). "Understanding Recent Crises in Emerging Markets", Economic Review, Federal Reserve Bank of Atlanta, $2^{\text {nd }}$ Quarter ,Georgia, U.S.A.: 6-16.

Cebenoyan a. Sinan and Philip E. Strahan, (2004). "Risk Management, capital structure and lending at banks", Journal of Banking and Finance 28: 19-43.

Corsetti, G, P. Pesenti, and N. Roubini, (1998). "Fundamental Determinants of the Asian Crisis: a preliminary empirical assessment", paper prepared for the JIMF-Fordham University Conference on "Perspectives on the Financial Crisis in Asia".

Cummins, J.D. and Sommer, D.W., (1996). "Capital and risk in property-liability 
insurance markets", Journal of Banking and Finance 20: 1069-1092.

Demirgunc-Kunt, A., (1989). "Deposit Institution Failures: A Review of the

Empirical Literature", Federal Reserve Bank of Cleveland, Economic Review, (Qtr. 4).

Elyasiani, E. and Mansur, I., (1998). "Sensitivity of the bank stock returns distribution to changes in the level and the volatility of interest rate: A GARCH-M model," Journal of Banking and Finance 22:535-563.

Fischer, K.P., Gueyie, J.P. and Ortiz, E., (2000). "Risk-taking and Charter Value of Commercial Banks' From the NAFTA Countries", paper presented at the $1^{\text {st }}$ International Banking and Finance Conference, Nikko Hotel, Kuala Lumpur, Malaysia.

Gallo, J.G, Apilado, V.P. and Kolari, J.W., (1996). "Commercial bank mutual fund activities: Implications for bank risk and profitability", Journal of Banking and Finance 22: 1775-1791.

Galloway, T.M., Lee, W.B. and Roden, D.M., (1997). 'Banks' changing incentives and opportunities for risk taking", Journal of Banking and Finance 21: 509527.

Hamada, Robert S., (1972). "Portfolio Analysis, Market Equilibrium and Corporate Finance", The Journal of Finance XXIV (1): 13-31

Hassan, K.M., (1993). "Capital market tests of Risk Exposure of Loan sales", Quarterly Journal of Business \& Economics 32 (1): 27.

Hassan, K.M, Karels, G.V. and Peterson, M.O., (1994). "Deposit Insurance, market discipline and off-balance sheet banking risk of large U.S. commercial banks", Journal of Banking and Finance 18: 575-593.

Kraft, Evan and Ljubinko, Jankov (2005). Does Speed kill? Lending booms and their consequences in Croatia, Journal of Banking and Finance 29 : 105 121.

Neal, R.S., (1996). "Credit Derivatives: New Financial Instruments for Controlling Credit Risk". FRB of Kansas City", Economic Review 81 (2): $15-57$.

Park,S., (1997). "Risk-taking behaviour of banks under regulation", Journal of Banking and Finance 21: 491-507.

Sharpe, W.F., (1963). “A Simplified Model for Portfolio Analysis", Management Science 9: 277-93.

Shrieves, Ronald, E and Dahl, D., (1992). "The Relationship between Risk and Capital in Commercial Banks", Journal of Banking and Finance 16: 439457.

Takayasu, K., and Yosie, Y., (2000). Non-performing Loan Issue Crucial to Asia's Economic Resurgence, Sakura Investment Research: 1-6 